\section{Slow Inactivation of Dry PCR Templates by UV Light}

\author{
Marilynn R. Fairfax, \\ Mark A. Metcalf, and \\ Richard W. Cone
}

Division of Virology, Department of Laboratory Medicine, University of Washington Medical Center, Seattle, Washington 98195
False-positive polymerase chain reactions (PCR) due to amplification of contaminating DNA are a constant problem despite rigorous safeguards. ${ }^{(1)}$ Ultraviolet (UV) irradiation has been shown to decontaminate solutions effectively. ${ }^{(2,3)}$ Recent work has shown that dry contaminating DNA may be brought into the setup area on hair, skin, (4) or gloves that have touched a surface inadvertently contaminated with dry DNA. ${ }^{(5)}$ Sarkar and Sommer ${ }^{(3)}$ have noted that dry DNA is more resistant to $U V$ inactivation. We did not find literature investigating the efficacy of UV light in inactivating the short sequences of dry DNA that might contaminate a PCR setup area.

To examine the effectiveness of the UV light technique, purified DNA from cells infected with human herpes virus 6 (HHV-6) was dried onto plastic tissue culture petri dishes (Costar; $1 \mu \mathrm{g}$ $\mathrm{DNA} / \mathrm{cm}^{2}$ ) and irradiated with two germicidal UV lamps for the times indicated in Figure 1 (ballast UF-36-2, lamps G36T6L, American Ultraviolet Company, Santa Anna, CA). The lamps were mounted on the ceiling of a fume hood at a distance of 1 meter from the working surface. Under these conditions, the incident near-UV radiation as measured at the working surface was
$400 \mu \mathrm{W} / \mathrm{cm}^{2}$ (Black-Ray UV Meter J225, San Gabriel, CA). (The University of Washington standard for biosafety hoods requires at least $160 \mu \mathrm{W} / \mathrm{cm}^{2}$ at the surface.) The DNA in each specimen was redissolved and serially diluted, and each dilution was amplified with three different HHV6-specific primer pairs. The sequences selected by these primer sets were the targets whose UV sensitivity was explored. The number of amplifiable templates remaining at each time point was estimated as described in the figure legend.

Approximately $5 \times 10^{8}$ copies of each template were present in the unirradiated aliquots used for PCR. This amount of DNA could theoretically contaminate $10^{8}$ reactions (at our detection limit of five copies) and could be found in $1 \mathrm{nl}$ of a fully saturated $100 \mu \mathrm{l}$ PCR mixture containing $5 \times 10^{13}$ primer pairs. After $30 \mathrm{~min}$ of UV irradiation, which is reported to inactivate many DNA species in solution by approximately five orders of magnitude, $(2,6)$ the ability of our dry DNA to serve as a PCR template was not decreased reproducibly (not shown). After $1 \mathrm{hr}$, amplifiable DNA was reduced to $5 \times 10^{7}$ copies (one order of magnitude). After $8 \mathrm{hr}$ of irradia-

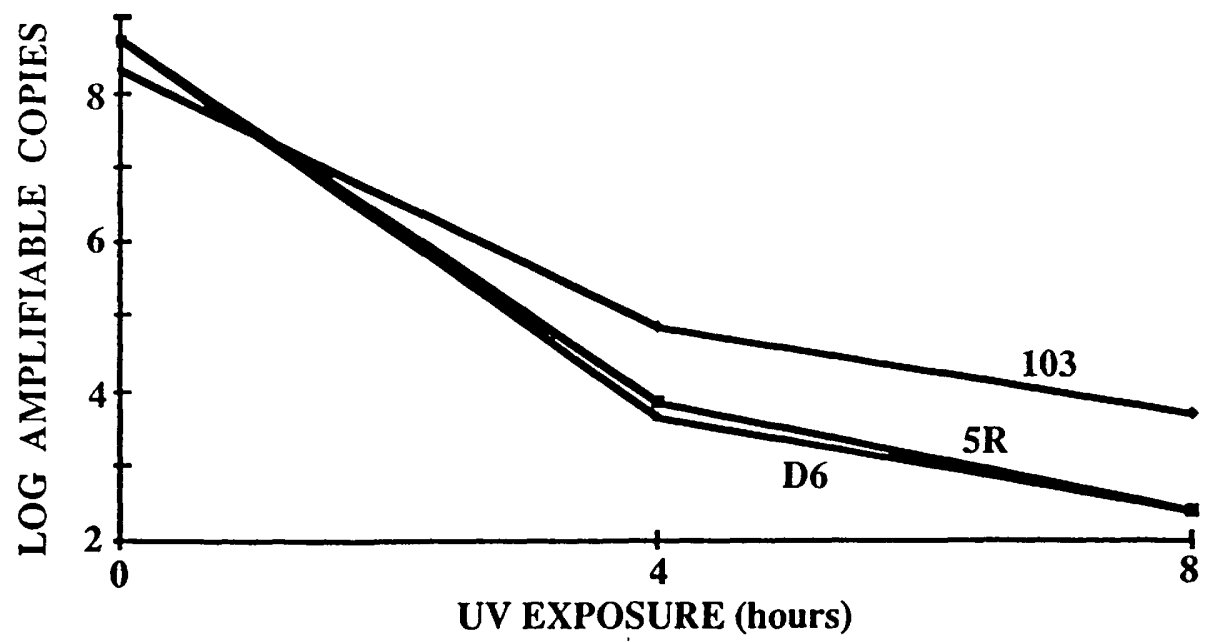

FICURE 1 UV inactivation of HHV-6 DNA as measured with three primer sets. After irradiation as described in the text, dried HHV-6-containing DNA was exposed to UV light for the times indicated in the figure, dissolved, serially diluted, and subjected to PCR ( 30 cycles) with each of three primer sets specific for different regions of the HHV-6 genome: 5R (223 bp, 42 dimerizable thymines, D6 (172 bp, 33 dimerizable thymines; sequence kindly provided by $\mathrm{R}$. Honess), and 103 (105 bp, 4 dimerizable thymines; plasmid kindly provided by P. Pellet). The product was detected by hybridization in solution with specific 32 P-labeled probes, followed by acrylamide gel electrophoresis and autoradiography. By comparison with the results from simultaneously amplified solutions containing known numbers of HHV-6 genomes, the number of amplifiable target sequences remaining at each time point was estimated. 
tion, 250 amplifiable copies of the longer, thymine-rich D6 and 5R templates remained, as compared to 5000 copies of the shorter, relatively thymine-poor 103 template. DNA in solution has been shown to vary more than $10^{4}$-fold in UV sensitivity depending on sequence length, and on thymine and cytosine content. $(2,3,6)$

UV irradiation inactivated our dry PCR templates in a time- and sequence-dependent fashion, albeit slowly. Based on these results, contaminating DNA could be significantly reduced after $8 \mathrm{hr}$ or more of irradiation with a germicidal UV bulb. Since UV lights can often be left on for $10 \mathrm{hr}$ or more per day, prolonged UV irradiation may be a practical means of partially inactivating dried PCR templates. However, the 10-fold reduction observed after $1 \mathrm{hr}$ of irradiation may not be adequate for preventing PCR contamination.

\section{ACKNOWLEDGMENT}

This work was supported by National Institutes of Health grant 1 R29 AI30648-01.

\section{REFERENCES}

1. Kwok, S. and R. Higuchi. 1989. Avoiding false positives with PCR. Nature 339: 237-238.

2. Sarkar, G. and S.S. Sommer. 1990. Shedding light on PCR contamination. Nature 343: 27.

3. Sarkar, G. and S. Sommer. 1990. More light on PCR contamination (letter). Nature 347: 340-341.

4. Kitchin, P.A., Z. Szotyori, C. Fromholc, and N. Almond. 1990. Avoidance of false positives (letter). Nature 344: 201.

5. Cone, R., A. Hobson, M.-L. Huang, and M. Fairfax. 1990. Polymerase chain reaction decontamination: The wipe test. Lancet 316: 686-687.

6. Cimino, G., K. Metchette, S. Isaacs, and Y. Zhu. 1990. More false-positive problems (letter). Nature 345: 773-774.

7. Gopal, M., B. Thomson, J. Fox, R. Tedder, and R. Honess. 1990. Detection by PCR of HHV-6 and EBV DNA in blood and oropharynx of healthy adults and HIV-seropositives (letter). Lancet 335: 1598-1599.

Received June 18, 1991; accepted in revised form August 9, 1991. 


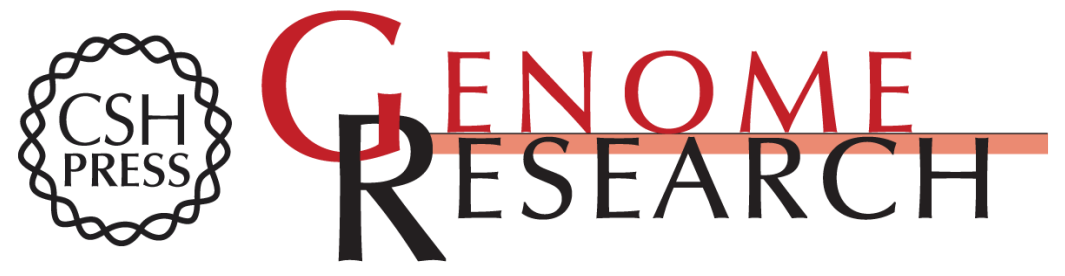

\section{Slow inactivation of dry PCR templates by UV light.}

M R Fairfax, M A Metcalf and R W Cone

Genome Res. 1991 1: 142-143

Access the most recent version at doi:10.1101/gr.1.2.142

\section{License}

Email Alerting Receive free email alerts when new articles cite this article - sign up in the box at the Service top right corner of the article or click here.

\section{Affordable, Accurate Sequencing.}

To subscribe to Genome Research go to: https://genome.cshlp.org/subscriptions 